\title{
Radiological Health Review of the Final \\ Environmental Impact Statement \\ Waste Isolation Pilot Plant \\ Volumes 1 and 2 \\ DOE/EIS-0026
}

Environmental Evaluation Group

Environmental Improvement Division

Health and Environment Department

State of New Mexico

January 1981

DISCLAIMER —— C

Neither the United States Government nor any agency thergot, nor any of their employees, makes any

warrenty, express or implied, or assu nees any leyal liability or responsibility for the accuracy.

completeness, or usefulness of any intormation, apparatus, product, or process difsclosed, or

represents that its use would not infringe privately awned rights. Feterence herein to any specific

commerciai product, process, or service by trade name, trademark. mantutacturee, or otherwise, does

nat necessarily constiune or imply is endorsenent, recommendation, or tavoring by the United

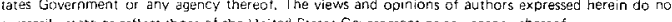




\section{CONTENTS}

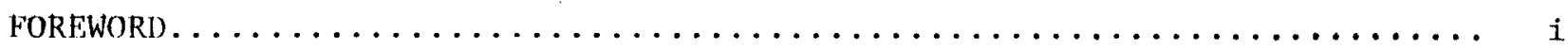

STAFF AND CONSULTANTS.............................

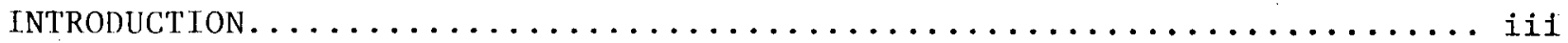

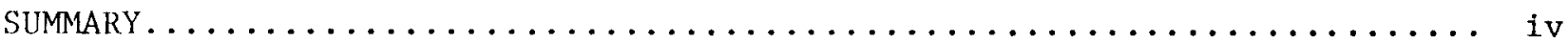

PRELIMINARY RADIOLOGICAL HEAJTH REVIEW OF THE FINAL ENVIRONMENTAL IMPACT

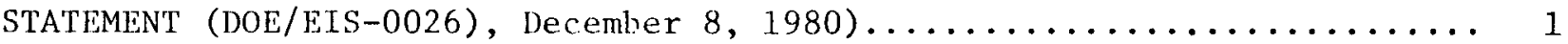

INTRODUCTION ...................................

INVENTORY OF RADIOACTIVE MATERIAL. .....................

RESOURCE EXTRACTION................................4

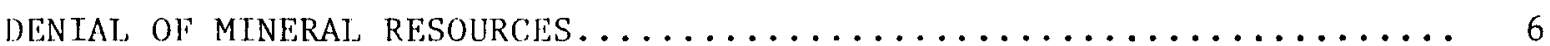

WASTE ACCEPTANCE CRTTPRTA......................... 7

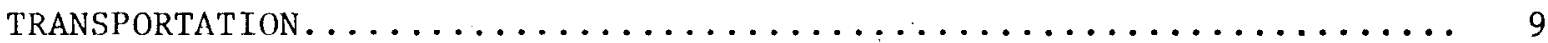

GEOLOGY, HYDROLOGY AND SITE CHARACTERIZATION . . . . . . . . . . . . 14

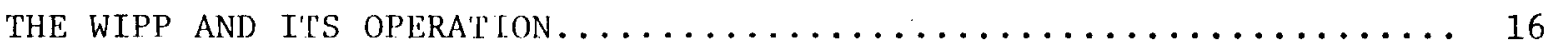

HIGH LEVEL WASTE................................ 19

EFFFCTS OF PLAN' OPERATTON, ACCTDENTS ANI IONG TERM EXPOSURES...... 20

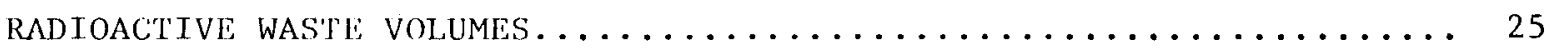

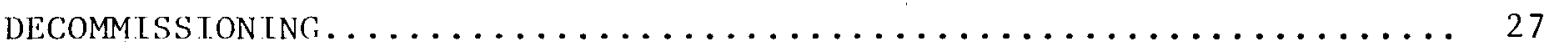

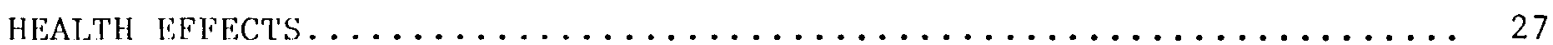

RADIOLOGICAI HEALTH REVIEW OF THE FINAL ENVIRONMENTAL IMPACT STATEMENT

(DOF/ETS-0026), Supplementary Comments to Review of Dec. 8, 1980, January

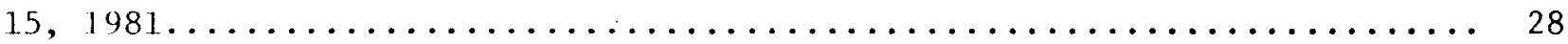

FETS EXECUTTVE SUMMARY .............................. 29

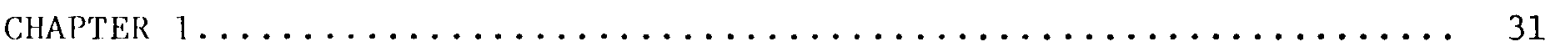




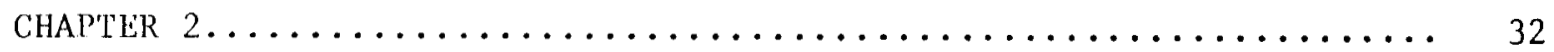

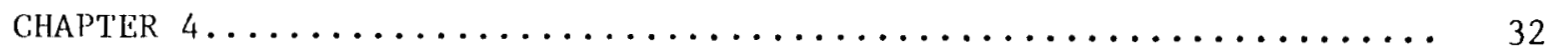

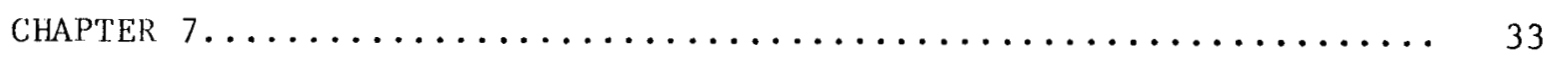

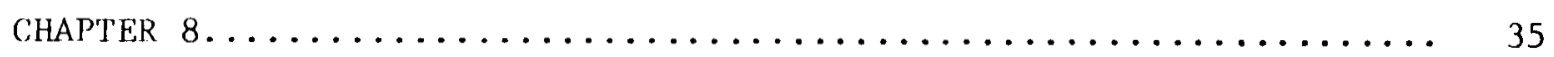

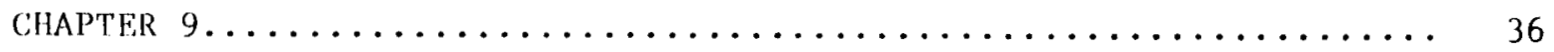

APPENDIX

D - Selection Criteria for the WIPP Site............... 39

E - Description of Waste Types................... 41

$J$ - Effluent and Environmental Measurements Programs.......... 42

NON-RADIOLOGICAL ENVTRONMENTAL ISSUES................ 44

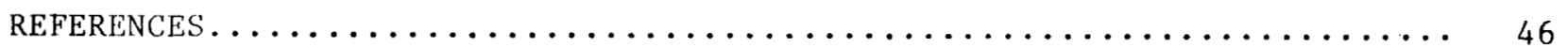


FOREWORD

The purpose of the Environmental Evaluation Group (EEG) is to conduct an independent technical evaluation of the potential radiation exposure to people from the proposed Federal radioactive Waste Isolation Pilot Plant (WIPP) near Carlsbad, in order to protect the public health and safety and ensure that there is minimal environmental degradation. The EEG is part of the Environmental Improvement Division, a component of the New Mexico Health and Environment Department -- the agency charged with the primary responsibility for protecting the health of the citizens of New Mexico.

The Group is neither a proponent nor an opponent of WIPP.

Analyses are conducted of reports issued by the U. S. Department of Energy (DOE) and its contractors, other Federal agencies and other organizations, as they relate to the potential health, safety and environmental impacts from WIPP.

The project is funded entirely by the U. S. Department of Energy through Contract DE-AC04-79AL10752 with the New Mexico Hea1th and Environment Department.

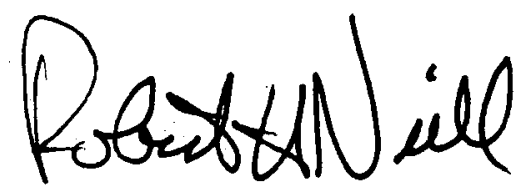

Robert H. Neill Director 


\section{STAFF AND CONSULTANTS}

Ann Bancroft, M.A.L., Librarian

Stephen T. Bard ${ }^{(1)}$, Ph.D., Environmental Modeler

James K. Channell, Ph.D., P.E., Environmental Engineer

Lokesh Chaturvedi, Ph.D., NMSU, Geological Consultant

Luz Elena Garcia, B.B.E., Administrative Secretary

Ashok Kalra, Ph.D., Geophysicist Consultant

Marsha11 S. Little ${ }^{(1)}$, M.S., Health Physicist

Jack M. Mobley, B.A., Sclentific Llaison Officer

Robert H. Nei11, M.S., Director

Lucy G. Rubio, Secretary III

Péter Spiegler (1) (2), Ph.D., Radiological Analyst

Peggy Tyler, Administrator

S. Marc Zand, Ph.D., Hydrologist

(1) Certified, American Board of Health Physics

(2) Certified, American College of Radiology 


\section{INTRODUCTION}

The Environmental Evaluation Group has reviewed the Final Environmental Impact Statement on WIPP (DOE/EIS 0026) and has submitted written comments to the U.S. Department of Energy. Due to the length and complexity of the documents, the EEG was not able to complete, to its satisfaction, a comprehensive review in sufficient time to meet the deadline of December 8,1980 . Thus, preliminary comments were transmitted on December 8 th and supported Governor King's November 4, 1980 request for a 45 day extension.

On January 15,1981 the final and more detailed supplemental comments were submitted. Both of these transmittals are incorporated in this report. 


\author{
RADIOLOGICAL HEALTH REVIEW OF FINAL ENVIRONMENTAL IMPACT \\ STATEMENT ON WASTE ISOLATION PILOT PLANT, DOE/EIS-0026, \\ VOL. I AND II, OCTOBER, 1980.
}

\begin{abstract}
SUMMARY
Pursuant to the requirements of the National Environmental Policy Act of 1969, the Department of Energy has provided in the Final Environmental Impact State (FEIS) a comprehensive review of the potential radiological impact of the proposed Waste Isolation Pilot Plant, referred to in the FEIS as. "the authorized alternative." The EEG has reviewed this document to determine (a) the changes made in comparison with the Draft Environmental Impact Statement (DEIS); (b) the adequacy of the DOE's evaluation of the potential radiological impact; (c) the thoroughness of the DOE's response to the comments of the EEG on the DEIS; and (d) other issues which should be addressed by DOE more fully prior to beginning construction of the WIPP.
\end{abstract}

Based on our review of the FEIS, the Department of Energy has incorporated and addressed the majority of the concerns, questions and recommendations that the EEG provided to them in our August 1979 review (Reference 2) of the Draft Environmental Impact Statement on WIPP and the FEIS provides a generally satisfactory evaluation of the potential radiological impact. There are, however, a number of areas that have yet to be adequately treated by DOE and should be acted upon and resolved prior to beginning construction of the WIPP. The more important issues are 1 isted below, and are discussed in more detail in our December 8, 1980 and January 15, 1981 comments on the FEIS.

1) EEG has referred to various statements and data in the FEIS, Geological Characterization Report on WIPP (Reference 12), and the Safety Analysis Report (Reference 8) which indicate possible instability in the area just north ( 1.2 to 3 miles) and southwest (less than 1 mile) of ERDA-9, and at depths near the repository horizon. EEG continues to have concern as to how this zone of anomalous seismic reflection data will. 
be further investigater. It does not appear that the SPDV program, as presently described, will provide sufficient information to evaluate the significance of these data. The EEG has also requested further information on brine reservoirs and dissolution processes near the site.

2) Nefther the FEIS, nor other published DOE documents, have provided information on the criteria to be used for the high-level experimental wastes to be temporarily stored at the WIPP repository. Also the DOE has failed to indicate the procedures to be used to assure that the Waste Acceptance Criteria for the $\mathrm{CH}$ and $\mathrm{RH}$ TRU waste will be met.

3) The DOE needs to provide more detailed information on the future control of the mineral and hydrocarbon resources at or near the site, and of the hazard analyses that led to the conclusion that resources at the site can be safely extracted.

4) The DOE needs to consider the consequences of other potential release scenarios which have been recomended by the EEG. 


\author{
Preliminary \\ Radiological Health Review \\ of the Final Environmental Impact Statement (DOE/EIS-0026) \\ Waste Isolation Pilot Plant, U. S. Department of Energy
}

Environmental Evaluation Group

Environmental Improvement Division

Health and Environment Department

State of New Mexico

December 8, 1980

$-1-$ 
RADIOLOGICAL HEALTH REVIEW OF FINAL ENVIRONMENTAL IMPACT STATEMENT ON WASTE ISOLATION PILOT PLANT DOE/EIS-0026, Vo1. I and II, October, 1980

\section{INTRODUCTION}

The Department of Energy appears to have incorporated and addressed the majority of the concerns, questions and recommendations that the EEG provided to them in our August 1979 review (Reference 2) of the Draft Environmental Impact Statement on WTPP.

There are, however, a number of areas that do not appear to have been adequately addressed. These and other areas are discussed in the following sections. The limited time available for this review does not permit us to determine with certainty the adequacy of either the FEIS or these preliminary comments. 
INVENTORY OF RADIOACTIVE MATERIAL

EEG recommended in September 1979 that the Final EIS contain estimates of the radioactivity to be present in the repository and the uncertainty associated with the estimates. That was not done, although page 9-127 of the Fris does show 539,000 curies of transuranic activity at 1000 years.

While the following table presents our estimates of the radioactivity, the information did not permit estimates of the uncertainties.

Radioactive Inventory of WIPP at the Time of Closure

\begin{tabular}{lccr} 
& $\begin{array}{c}\text { Radioactivity } \\
\text { (Curies) }\end{array}$ & Emplacement & \multicolumn{1}{c}{$\begin{array}{c}\text { Volume } \\
\left(\mathrm{ft}^{3}\right)\end{array}$} \\
\hline CH-TRU & $2,800,000$ & Permanent & $6,200,000$ \\
RH-TRU & $5,100,000$ & Permanent & 250,000 \\
HLW & $17,000,000$ & Temporary & 150 \\
\hline
\end{tabular}




\section{RESOURCE EXTRACTION}

There has been a slight shift in language in the Final EIS on the degree of mineral extraction that may be permitted in the various zones. Exact comparisons are not possible because various sections in both Draft and Final give different impressions of what may be permitted. The wording in the Final EIS appears to be predicting a greater degree of extraction, especia1ly in the inner zones. These statements are paraphrased below.

Draft EIS - On page 3-6 it is stated that Zone IV will eventually be released for resource exploitation (no mention of other zones). On page 8-1 it is said that only DOE drilling would be permitted in Zones I \& II; possible resource extraction would be allowed in Zone ITI pending outcome of studies; potash mining (no solution mining) and hydrocarbon extraction (no secondary recovery) may be permitted by DOE. On page 9-21 it is stated that mining and drilling may be permitted in Zone IV but hydrocarbons could be extracted from under Zone IV by deviated drilling from outside Zone IV. There is no mention of possible recovery from under Zones I, II, or III. On page 11-1 the statement is made that it may eventually be possible to recover hydrocarbons from beneath all zones by deviated drilling from outside zone TII.

Final EIS - The Executive Summary (page 6-14) says that hydrocarbon resources can be exploited by deviated drilling from outside zone IV or by vertical and deviated drilling within zone IV. Potash reserves in Zone IV may be mined; the consequences of mining in Zones 1,. IT, III are current1y being evaluated. Page 4-5 says that mining for hydrocarbons and potash in Zone IV is expected and that all the natural gas could be recovered by deviated drilling from Zone IV. On page 9-27 the words "may" and "would" are both used in reference to potash and hydrocarbon extraction in Zone IV. Statements on page 11-1 say that potash and hydrocarbon extraction from zone IV will not affect site integrity but it is not clear what the consequences would be of mining langbeinite from the inner control zones.

Our concerns with the issues are:

1. It is uncertain just what restrictions DOE presently plans to put on extraction from Zone $\mathrm{LV}$ and for deviated drilling beneath the inner zones. 
2. The possibility of potash extraction in the inner zones of the site directly above or near the storage rooms is of particular interest. Mining activity, with possible blasting, 400 feet above the waste horizon could significantly reduce the safety factors that would be expected from storage at a depth of 2150 feet below the surface in a formation that is 2,000 feet thick.

3. We have not seen the evaluations that led to the language in the Draft nor the subsequent evaluations that apparently give DOE a greater confidence in the ability to extract minerals without threatening site integrity. It will be necessary to review these reports in order to be assured that DOE's conclusions are valid.

4. The time table for making these decisions and the procedure for doing so needs to be known so that FEG can have input into this process. 
DENIAL OF MINERAL RESOURCES

Section 9.2.3.1 and related sections of the FEIS clearly describe the mineral and hydrocarbon reserves at the site, their relative economic importance, and attractiveness for potential extraction in the future. EEG still has concerns about this possible future attractiveness and the methodologies for mineral and hydrocarbon extraction currently proposed by DOE. These concerns are clearly stated in this FEIS review under sections entitled "Decommissioning" and "Resource Extraction."

EEG's comilation of references on "People-Made Penetrations" and "Conf1ict with Natural Resources" contained in EEG-1 (Reference \# 10) inventoried in detail recommendations regarding repository sites with mineral and hydrocarbon resources. This and subsequent work in this major issue area has led EEG to emphasize the necessity to quantitate potential radiation risks associated with resource extraction at the site as currently proposed by DOE and the long-term risks with future extraction after site decommissioning. 
WASTE ACCEPTANCE CRITERIA

Except for one change (the criterion for restricting toxic materials), Chapter 5 on Waste Acceptance Criteria is unresponsive to the comments of EEG. (See Reference 4 and pp. 4, and 20-24, Reference 2.) Because the SAR (Reference 8) makes it clear that the contents of the waste shipments will not be analyzed at WIPP to determine compliance with the criteria limiting toxic and corrosive material, sludges, pyrophorics, powders, and fissile material, the FEIS should have indicated how compliance will be assured, or evaluated the environmental impact assuming no compliance.

Page 15-36 of the FFIS states that the quality assurance system to insure compliance by the shippers with the WAC will be developed before the start of the WIPP operations. However, these procedures are germane to the hazard evaluation and environmental impact of the WIPP operations and therefore should have been included in the FEIS.

The FEIS discusses the possibility of processing the waste before shipment, and there is a strong implication that the waste will be processed by slag pyrolysis. If so, the WAC would be met. If the waste is not processed how will compliance be assured? What methods and what audit procedures will be used?

On page 9-176 of the FEIS, it is recognized that overpacking of the waste containers at INEL would not provide compliance with Waste Acceptance Criteria. Yet the overpacking procedures described in Section 9.8 indicate transfer of the packages to the rail car and then to the WIPP with no plans indicated for evaluation of the waste to assure compliance with WAC. There are also no plans to evaluate the waste at WTPP.

On page 8-26 of the FEIS, we note, a1so, that waste packages which would not meet the WAC may be shipped from WIPP to other sites for processing. Criteria are needed for such shipments, and DOE should evaluate the possible hazards associated with such shipments.

l.t was noted that the wording of the criteria in Chapter 5 remains ambiguous 
or misleading. There is clear implication that WIPP will analyze the waste to determine if it will be accepted, and have it returned if it is unacceptable. EEG objects to such wording, and urges that it be revised to clearly indicate that the shipper--not WIPP--is responsible if the criteria are not met. Furthermore ambiguities resulting from the phrase, "will be accepted" or "will not be accepted" should not be used. The DOE legal staff should also review the criteria to be certain that the wording is construed as legally mandatory on the part of the shipper, and that vague statements will be revised as previously recommended by EEG (References 2 and 4 ).

We also note small inconsistancles between the FEIS Waste Acceptance Criteria and the criteria published in WIPP-DOE-069, Reference 5. For example, the criterion in the FEIS 1imiting gas generation states the total gas produced from contact-handled waste by all mechanism may not exceed 10 moles per cubic meter of disposal room in the WIPP. The WIPP-DOE-069 1imits the gas to 10 moles per cubic meter of disposal room per year in the WIPP. Is this an inadvertent deviation or has the criterion been changed? Also the FEIS criterion for "immobilization" indicates that no dry powders "will be accepted," whereas WIPP-DOE-069 iimits the dry powders to $1 \%$ of the waste matrix weight.

Neither the FEIS nor any other DOE report has provided criteria for the high level waste. These criteria also are needed for the evaluation of the environmental impact of WIPP.

Another concern which has not been addressed in the FEIS is how the WIPP faci1ity will assure that the drums do not contain explosive gas mixtures at the time of retrieval, should retrieva1 prove necessary. (See p. 3-15, Reference 3.) 
TRANSPORTATTON

We recommended that a number of dosage estimates be performed including acts of sabotage, doses to emergency workers, exposures to people in cars stopped next to a truck with radioactive waste. These estimates are included in the FEIS.

DOF did not include our recommenlation to estimate doses from the ingestion of contaminated lood following a transportation accident with a release of radioactive material based on their belief that corrective action measures including the condemnation of food and decontamination of farmland would be promptly taken. EEG believes that an assessment of possible radiation doses by these pathways is important for two reasons:

1) to indicate if radiation doses could be high enough to require short-term protective measures or long-term land use controls;

2) to estimate the amount of low-level, long-term dose that may be unavoidable if such a release occurs.

We have published such an analysis entitled Calculated Radiation Doses From Deposition of Material Released in Hypothetical Transportation Accidents Involving WIPP-Related Radioactive Wastes, by Dr. James K. ChanneII, EEG-5 (Reference 6).

Mul detailed comments concerning, infotmation contained in Chapter 6 of the lels are provided below:

6-4* The Regulatory responsibilities of the New Mexico State Government and the Federal Government affecting the transportation of radioactive waste to WIPP need to be clarified. EEG will bring this matter up to the appropriate agencies.

6-12 According to the FEIS, CH-TRU waste shipped from Hanford, LASL and SRL wil1 not be directly considered in the impact ana1ysis. The following analysis indicates that $1 / 3$ of the CH-TRU waste to be shipped by volume is not being considored in the impact statement for dosage estimates in transportation.

\footnotetext{
* These numbers refer to the chapter and page number of the FEIS.
} 


\begin{tabular}{|c|c|c|c|}
\hline Source & $\begin{array}{c}\text { Considered in } \\
\text { FEIS }\end{array}$ & $10^{3} \mathrm{cu} \mathrm{ft}^{\mathrm{a}}$ & $\begin{array}{c}\text { Dose Calculations } \\
\text { in FEIS } \\
\end{array}$ \\
\hline INEL & yes & $2376^{a}$ & yes \\
\hline Rocky Flats Plant & yes & $100^{b}$ & yes \\
\hline Hanford & no & $855^{a}$ & no \\
\hline LASL & no & $249^{a}$ & no \\
\hline SRL & no & $109^{\mathrm{a}}$ & no \\
\hline
\end{tabular}

6-13 The truck routing concept used by DOE for transuranic and high leve1 waste appears different from NRC guides relating to the shipment of spent fuel. Both use interstate highways but NRC bypasses large cities such as Albuquerque whereas Figure 6-3 on page 6-15 appears to have the trucks pass through the cities.

6-15 According to the FEIS the transportation analysis will not include RII-TRU from ORNL, LASI and Hanford. From the following analysis, $78 \%(69 / 89)$ of the RH-TRU waste by volume to be shipped to WIPP is not being considered in the FEIS.

\section{RH TRU (1986)}

$\begin{array}{lcccc}\text { Source } & \begin{array}{c}\text { Considered in } \\ \text { FEIS }\end{array} & \frac{10^{3} \mathrm{cu} \mathrm{ft}^{\mathrm{a}}}{2} & \begin{array}{c}\text { Dosage Calculation } \\ \text { in FEIS }\end{array} \\ \text { INEL } & \text { yes } & & 20 & \text { yes } \\ \text { ORNL } & \text { no } & 52 & \text { no } \\ \text { Hanford } & \text { no } & 8 & \text { no } \\ \text { LASL } & \text { no } & \text { Total } & -\frac{9}{9} & \text { no } \\ \text { a } & & & & \end{array}$


6-17 The FEIS calculations of the radiological impacts of waste transport under normal condition assume that $370,000 \mathrm{ft}^{3}$ of $\mathrm{CH}$ waste and 4,200 $\mathrm{ft}^{3}$ or RH waste will be transported annually from INEL and RFP to WIPP (page 6-17). The breakdown of the data is given in tables 6-2, 6-6, 6-7, and 6-8 of the FEIS.

The calculations may not be conservative for the following reasons: The WIPP design criteria report, WIPP DOE 7.1 , states that for a threeshift-per-day operation, the annual design capacity will be $1,200,000 \mathrm{ft}^{3}$ of $\mathrm{CH}-$ waste and $10,000 \mathrm{ft}^{3}$ of RH-waste; for a one-shift-per-day, the annual design capacity wil1 be $500,000 \mathrm{ft}^{3}$ of $\mathrm{CH}$ waste and $4,000 \mathrm{ft}^{3}$ of $\mathrm{RH}$-waste (the last number is estimated by EEG; it is not mentioned in the design criteria). The design criteria also state that the estimated rate of shipment for CH-waste for 9 years (year 4 to year 13) will be 500,000 $\mathrm{ft}^{3} / \mathrm{y}$. Further, most of the RH-waste is stored at ORNL which is considerably further away from WIPP than INEL and RFP (Table 2-3, page 2-17).

It is possible that waste will be shipped to WIPP at rates greater than $370,000 \mathrm{ft}^{3} / \mathrm{y}$ because of the large backlog.

The title of Table 6-2 "Volume of Waste Shipped per Year" is misleading since it identifles only 2 of the 8 sites shipping waste to WIPP.

6-18 According to the FEIS, very small quantities of HLW will be shipped to WIPP for experiments.". This is not so. Our calculations show this to be 17 million curies which is more than twice as large as the combined $\mathrm{CH}$ and $\mathrm{RH}, \mathrm{TRU}$ waste to be permanently emplaced.

6-1.9 The waste volume being shipped from INEL by truck in Table 6-4 should be $1,100 \mathrm{ft}^{3} \mathrm{RH}-\mathrm{T} R \mathrm{R}$, not $110,000 \mathrm{ft}^{3}$. 
6-19;1 Clarification is needed to evaluate the impact of high-level waste for experiment. Section 6.5.3 of the FEIS estimates the equivalent of 40 canisters of high-level waste. The SAR mentions 60 canisters. Section 8.9.5 (p.8-48) of the FEIS mentions 20 canisters per waste form. Clarification is needed between the FEIS and the SAR.

$6-24 \&$ $6-25$

The collective doses for INEL and RFP in tables 6-6, 6-7, and 6-8 are the same as those shown in table 6-9 and 6-10 of the DEIS. The collective doses for shipments from Hanford, LASL, and SRP have been omitted even though in the DEIS they amount to about $50 \%$ of the total collective dose. One might conclude that the radiological impact has been underestimated in the FEIS. This should he clarified.

6-26 l'he statement that the most-exposed person receives an annual dose of 0.15 mrem from the normal transport of radioactive waste requires clarification. In fact, in the same paragraph a dose of 1.6 mrem is quoted for a person waiting 2 hours behind a stalled truck. EEG has obtained doses greater than 0.15 mrem for the following four plausible scenarios:

Case $\mathrm{mrem} / \mathrm{yr}$ Assumptions

Individual is exposed to $20 \%$ of all trucks stopped for 1 minute at a distance of $25^{\prime}$ for 1 hour at a distance of $100^{\prime}$

Individual is exposed to $25 \%$ of all trucks stopped for 1 hour at a distance of 50' of all trucks at a distance of 5 feet for a time interval of $2 \mathrm{~min} / \mathrm{truck}$. 
It appears that the radiological impact for high level waste is based on a one-way scenario of 40 canisters distributed in 6 shipments over the lifetime of the repository. It should include an equal number of shipments leaving the repository after the experimental phase is over. Furthermore, the description of the high level waste experiment (in Chapter 8, pages 8-48,49) suggest that more than 40 canisters might be necessary.

$6-31$

In the accidents analyzed in the FEIS, it is assumed that inhalation \& 6-34 of radionuclides is the primary pathway to people. It is assumed that administrative procedures used in the clean up procedure will prevent radionuclides from reaching the food chain. EEG disagrees with this assumption and has pointed out in the report EEG-5--Ca1culated Radiation Doses From Deposition of Materia1 Released in Hypothetical Transportation Accidents Involving WIPPRelated Radioactive Wastes, by J. K. Channe11 --that doses through food pathways are greater than zero even after protective measures are taken.

$6-41$

The emergency procedure section does not address itself to the following questions: If an accident occurs and the shipment is damaged, will the damaged shipment be forwarded to WIPP or will it be returned to shipper? If forwarded to WIPP, is the design of the waste handling building adequate to handle large damaged shipments?

A number of additional dosage calculations had been identified by EEG in report EEG-3. The status of these calculations is as follows:

1. Sabotage

2. Emergency Workers

3. Stopped Automobile

4. Retrieved wastes

5. Contamination of Food Supply

6. D\& D of Hanford

7. Individual doses as well as population

8. Diffuse sources
Tncluded in FEIS

Included

Tncluded

Not Included

Not Included

Not Included

Included

Not Included in FEIS (We agree) 
GEOLOGY, HYDROLOGY AND SITE CHARACTERIZATION

Our preliminary review of the geology, hydrology and site characterization information as contained in the FEIS indicates that several sections have been expanded and better explained than that presented in the DEIS. However, there is still insufficient treatment of potential problem areas as discussed in more detail below:

\section{1) Disturbed Zone or Zone of Anomalous Seismic Reflection}

This topic is briefly mentioned in the Geology Summary on pages 7-16 to 7-19 as "an anticline...on the upper Castile is located at the northern edge of Control Zone II." A1though more details concerning this zone is provided on page 7-42, the FEIS should have more clearly reflected the uncertainty, controversy and concern regarding the potential implications of this zone to the future integrity of the repository. The EEG has provided discussion of this issue in commenting on the DEIS (See EEG-2 published as Appendix III, EEG-3, Reference 2). The FEIS has not adequately addressed these comments. For example, on page 7-29, the FEIS discusses various suspected dissolution features present in sections 9 and 17 of T22S, R31E, but fails to point out that these features coincide with the zone of anomolous reflection, the deprission in MB 124, and is close to the apparent anticline in the Castile. Also, on page 7-42, the FEIS explains the anomolous seismic reflections as "relatively tigtt folding or a discontinuity in the upper Castile." This does not adequately explain the phenomena and EEG believes that a more definitive explanation based on additional data is necessary before the site is judged acceptable for the repository.

\section{2) Brine Reservoirs}

This subject is discussed in the FEIS on pages 7-33 to.7-47, particularly section 7.3.5. Although this topic has been treated more extensively in the FEIS, it should have contained more data on the location of known artesian brine flows, and the differing views as to their origin and significance to the adequacy of the WIPP site. (Further discussion of this issue is contained in BEG Reports, References 7 and 9).

\section{3) Dissolution Processes}

The FEIS provided a clearer discussion of this issue than did the DEIS, but did not provide new data, nor were the various contrasting views 
adequately presented. For example, the discussion on page 7-29 failed to mention the Bell Lake Sink and Slick Sink, and the views of Anderson as to their possible deep seated origin. Also on page 7-100, the last paragraph is misleading with respect to the Anderson citation. His 1978 paper indicated that the active dissolution front in the Salado could reach the WIPP site in 50,000 years, but he believes the advance effects of deep dissolution may already have affected the repository area and vicinity. Page 7-27, paragraph 4 refers to the lamprophyre dike which is shown in Figure 7-13. Is it not possible that offshoots of the dike and perhaps sills may exist in the Salado near the site? Would this provide a preferential path for fluids in the event of a breach? The zone of anomolous seismic reflection may be evidence of deep dissolution. (For further discussion by EEG of this issue see References 7 and 9).

\section{4) Effect of Impurities in Salt}

Page 7-35, paragraph 5, indicates that the halite beds at the repository horizon are $97 \%$ halite, however there are also present many clay seams. What is the fraction of halite in the repository mass? The effect of these clay minerals on the repository should be based on in situ studies and should be known before a final decision is made on the adequacy of the site.

5) Site and Preliminary Design Validation Program (SPDV)

Under section 8.9, the FEIS provides very useful information on the research and development program for the proposed repository, including the in situ validation program. We recognize the need for the SPDV program, and note that it will obtain valuable data for site validation which cannot be obtained by other means. We hope that more details will be made available on the experiments in order that other groups might provide comments on these anticipated experiments. We note that one of the objectives will be to explore the undeveloped portion of the planned repository by horizontal core holes. Our preliminary evaluation of these plans indicate that the horizontal core will not extend into the zone of anomolous reflection discussed in section 1 above, and therefore definitive datia concerning the significance of this zone to the repository integrity will still be needed. How will this issue be resolved? We note that the underground area covered by the SPDV program will be located within about 14 acres or about $10 \%$ of the total repository. At what point and on what bases will a final decision be made on construction of the complete repository? 
THE WIPP AND ITS OPERATTON

The following comments address the more important operational uncertainties that have been noted in our review of the information in Chapter 8.

\section{Shaft}

$8-11^{*}$ The $12^{\prime}$ shaft will be bored to a depth of 2300 feet. This is inconsistent with 8-14 paragraph 2 which makes the following statement:

"Starting at the bottom of the 12-foot-diameter shaft, horizontal excavation in the Salado salt will produce a network of underground cavities." The repository. is at a depth of 2150 feet. Also, the hoist drop accident assumes that there is only $40^{\prime}$ between the repository level and the bottom of the shaft.

Since the repository will be located at 2150 feet, why drill the SPIJV shaft to 2300 feet? This additional depth may decrease the factor of safety of a vertical connection if a brine reservoir is located in the upper Castile similar to ERDA-6.

\section{Facility Layout}

8-17 The FEIS indicates that the underground development of the repository will be due north from the shafts (page 8-17, Figure $8-9$ ). In the DEIS the direction is due west (page 8-16, Figure 8-11). Is there a final decision on the orientation to the north? If so, why? If no decision has been made, what criteria will be used to determine the direction of development?

8-19 Figure 8-10 of FEIS shows a significantly different layout in the eastern area of the waste-handling building different from the drawings of Section WBE-41 of the Title I study. Which is more up to date?

\footnotetext{
* These numbers refer to the page numbers of Chapter 8 of the FEIS.
} 
Ventilation

8-21 The paragraph states the following: "To confine radioactive material, the air-cleaning system will pass the air through banks of highefficiency particulate air (HEPA) filters." This statement is too general since the disposal exhaust filtration building is a surface facility in which the air will pass through HEPA filtration only if radioactivity is detected by monitors. More information is needed on the delay time for conversion from an unfiltered system to a filtered system. How much unfiltered air would be released during this transition?

8-32 "The first stage of the filtration system in the waste-handling building wil1 consist of 200 HEPA filters in paralle1." The Title I study reveals that the filtration system of the waste-handling building consists of 17 customized two stage HePA filters. Each unit will also have a prefiller. the units will be customized and their drawings do not exist at this time. The conclusion that 200 HePA filters are required appears incorrect.

Rad-Waste and Gaseous Releases

8-25 The paragraph at the top of the page states the following: "These systems have sufficient surge capacity to handle waste produced during postulated accidents..." This is contradicted by the paragraph at the bottom of the page which states the following: "In the unlikely event of a fire..., contaminated water will be processed by a portable liquid-radwaste-processing system brought onto the site after the fire." The portable system is not mentioned again. Its availability and possible location of use should be clarified.

8-28 The FEIS discusses possible pathways for the release of $\mathrm{CH}$ and RH TRU waste but does not address HLW. ("Surface contamination of HLW canisters are available for release," page 8-31). Information is needed on the possible pathways for HLW.

8-30 Table 8-5 estimates that the curies of radon gas released from the repository will be much greater than that due to man-made radiation. 
EEG pointed out in commenting on the DEIS that these estimates were not obtained from site-specific data and recommended that radon measurements be taken at the site before and after construction to evaluate the amount of radon present. DOE did not respond to this comment. We still believe that radon should be measured to see if levels might be high enough to be a problem for underground workers and to estimate radiation doses to the public.

8-36 While the FEIS estimates the amount of gas produced from the underground waste experiments of $150 \mathrm{ft}^{3} / \mathrm{y}$, it does not present the estimate of $6,000,000 \mathrm{ft}^{3} / \mathrm{y}$ from decomposition of the $\mathrm{CH}$ and $\mathrm{RH}$ TRU waste.

\section{Waste Experiments}

8-50 The paragraph suggests that the retrieval process will be a difficult task since the "volume of contaminated salt is expected to equal the volume of waste removed." Large volumes of salt might be involved.

If necessary to retrieve wastes, where will they be sent? Will DOE establish criteria for retrieval of $\mathrm{CH}$ and $\mathrm{RH}$, and when will these be available? This information is necessary to evaluate the radiological impact of the retrieval process.

8-51 We are pleased to see the expanded section of 8.10 .3 on the retrieval of HLW. The section does not state the destination of the waste. We believe that this should be included in the experimental plan. 
We were pleased to note that the information on the Defense High Level Waste (HLW) experiments has been expanded in Chapter 8 . The purpose and justification of these experiments is we11 stated in sections 8.9 .3 and 8.9.4. However, the methols described in section 8.9.5, do not allow a clear evaluation of the radiological impact. Two classes of experiments are described but it is not clear if there will be more than one waste form per class. Therefore, it is difficut to estimate the total amount of radioactivity involved. It is emphasized that the HLW will be retrieved after the conclusion of the experiments, but since the waste handling building has only overpacking capability, it is difficult to envision how the HLW will be repackaged so that it can leave the plant in compliance with transportation regulations and DOE criteria.

The radiological impact of shipping these wastes from the repository at the end of the experiments has not been evaluated and it should be. Also, there is a need for shipping criteria for the HLW, both to the site and after retrieval.

More information is needed on the fate of the HLW at the end of the experiments. The impression given in the FEIS (page 15-45) that DOE has no idea where the waste will go is troubling. What laboratories might receive these wastes shipments for analysis? Where would any full-sized canisters that did not need laboratory evaluation be sent? Might some of these canisters remain at the WIPP site if a radiological evaluation at the end of the experiment indicated this would result in the lowest radiation doses to workers and the public?

FEC believes the HLW experiments have more potential for significant occupational doses and site contamination than the other operations and we plan to thoroughly review the detailed plans for individual experiments as they become available. 
We are pleased that the FEIS has addressed a number of our suggestions for cxpinding the potential scenarios necessary to better assess the potential radiological risks both during the operational phase and over the long-term.

One of our primary conccrns centers around the potential for eventual human intrusion. We believe this is a credible scenario particularly because of the mineral and hydrocarbon resources in the region.

In addition to the intrusion scenarios addressed in the FEIS we repeat our recommendations made in the DEIS review for the following scenarios:

1) A connection is made between the repository, a high pressure brine reservoir and the surface.

2) Fffects of high pressure gas formation, generated by organic decomposition of the wiste, acts as a driving mechanism in bringing waste to the surface. (General population)

3) Generate dosage estimates using the DOE generic Waste Isolation Safety Assessment Program (WISAP) model currently under development by the Battelle Northwest Laboratories. (General Population)

4) Solution mining for sylvite or langbeinite takes place leading to breach of the decommissioned repository and release of radionuclides.

'hiesc comments and others relating to the information contained in Chapter 9 of the FEIS are discussed below:

T. Operational ixposures

9-40 Routine occupational radiation exposures (man-rem) expected during normal operations are given in Table 9-26. In order to evaluate Lhese estimates we will need the assumntions upon which these were based. 
9-107 Doses and dose commitments from accident scenarios were calculated to an individual living at James Ranch (Table 9-52). The EEG recommendation in the DEIS review that doses be computed at the NW site boundary and for transients in zones II, III, and IV was ignored. We still believe these should be made.

9- 117 The Chapter 9 assumption that exhaust air from underground waste handling and storage areas passes through HEPA filters is inconsistent with statements in Chapter 8 . Since the absence of filters can result in a substantial increase in doses from particulates, it is important to clarify this point. In addition, more detailed information is needed on the response sensitivity levels which activates the switching of the ventilation air stream through the HEPA filters, including response times, for both fires and increased radioactive particulates in the mine atmosphere.

The following areas of concern were raised on the DEIS (EEG-3) but were not addressed in the FEIS report by DOE and we request that they be addressed:

1) Is there a possiblity that Radon-222 and daughters could pose an occupational problem?

2.) Is there any possibility of encountering a methane gas pocket in bedded salt which could cause an explosion?

\section{Long-Term Exposures}

In evaluating the long-term radiological consequences of the WIPP repository, the FEIS has considered the same 5 scenarios for release of radionuclides as considered in the DEIS. In commenting on the DEIS, EEC had recommended the following additional scenarios be considered (Reference 2 , pages 81,90$)$ :

1) Build-up in the environment from radionuclides in water removed from the Pecos River for irrigation, incorporated into soil and plants, and cycled in food and man over long periods of time.

(Cenera.l Population) 
2) Generate dosage estimates using the DOE generic Waste Isolation Safety Assessment Program (WISAP) model currently under development by the Bartelle Northwest Laboratories.

(General Population)

3) A connection is made between the Delaware Mountain Group aquifer, the repository and the surface.

(Genera1 Population)

4) A connection is made between the repository, a high pressure brine reservoir and the surface.

5) Effects of high pressure gas formation, generated by organic decomposition of the waste, acts as a driving mechanism in bringing waste to the surface.

(Genera1 Population)

6) Well water becomes contaminated and is used for irrigation or stock watering.

7) Solution mining for salt takes place.

\section{Scenario Reconmendation 1}

The FETS indicates on page 15-30 that the consequences of using contaminated water below Malaga Bend for irrigation purposes as recommended is being studjed, and the results will be included in the WIPP Safety Analysis Report SAR. The DOE should provide an estimate as to when the results will be available.

\section{Scenario Recommendation 3}

Our recommendation \# 3 is discussed on p. 15-29. DOE concludes that a connection between the delaware Mountain Group aquifer, the repository and the surface is not realistic, because the hydraulic head of the aquifer is too small to allow direct releases of brine to the surface. We will review this conclusion. 
Scenario Recommendation 4

Page 15-29 also rejects the brine-pocket scenario in recommendation $\$$ 非 as being highly unlikely. We disagree with this conclusion for two reasons: (1) the well at ERDA-6 involved the "accidental" contact with a pressurized brine pocket that did flow to the surface; and (2) there have been several other encounters with brine reservoirs in the Castile in the Delaware Basin, which have involved surface flow, and at least one of these encounters (the Hudson-Belco) was not associated with the "deformation zone." (See additional discussion under "Geology and Site Characterization.") Therefore, we remain convinced that there is insufficient information on the origin and location of brine reservoirs to conclude that a connection at some future date between a brine-pocket, the decommissioned repository, and the surface (through a well) is not i plausible means for radionuclide release.

\section{Sccnario Recommendation 6}

We were pleased to note on page 15-30 of the FEIS that our recommendation \#6 concerning the radiation dose incurred by the use of well water taken downstream from a breached repository is to be analyzed by DOE. The EEG is also evaluating this scenario. Target dates for completion of studies in progress or to be initiated by DOE should be provided.

\section{Scenario Recommendation 7}

Page 9-145 (Section 9.7.1.6) of the FEIS provided a helpful discussion of the potential for solution mining in the vicinity of the decommissioned repository. We agree that such a scenario in our recommendation \# 7 for halite has a very low probability. Nonetheless, the difficulty of predicting the conditions far into the future, and the availability of minerals sylvite and langbeinite warrant evaluation of this scenario for these minerals. No reasons were given in the FEIS for rejecting scenarios 2 and 5 . We continue to believe that these scenarios should be considered.

\section{IIT. Additional Comments}

9-127 We are pleased that DOE has followed our suggestion to show the inventory of radioactive waste. At 1000 years it is 539,000 curies. DOE should also have indicated the activity at the time of closure which we estimate to be 7,800,000 curies. Also helpful would be an estimate of the error bounds associated with the inventory. 
9-1.07 The source terms in Table 9-50 and 9-51 of FEIS are considerably Table higher than those in Table $9-23$ and 9-24 of the DEIS. The dose 9-52 commitments in Table 9-52 of FEIS are also substantially higher than those in table $9-25$ of DEIS. However, for the $\mathrm{CH}$-area accidents, the ratios of the source terms (FEIS/DEIS) do not equal the ratios of the dose commitments (FEIS/DEIS). This is questionable since the quantity of activity has changed, not the isotope spectra. 
RADIOACTIVE WASTE VOLUMES

The FEIS states the repository would receive over a 25 -year period 6.2 million cubic feet of $\mathrm{CH}$-TRU wastes. This would include all wastes presently stored at INEL, two-thirds of a11 waste generated at DOE facilities from the present until 1990, and a11 DOE wastes generated from 1990 to 2003. Simi.lar (though not exact) statements are made on pages $2-17,18$. The transportation analyses assume wastes will come only from INEL, and RFP and would be shipped at a rate of 370,000 (Table 6-2, page 6-17) or 390,000 (Table 6-4, page 6-19) cubic feet per year. The amounts of new waste produced per ycar and the length of time it takes to fill the repository do not agree completely between these references but the differences are probably not important.

These statements lead to the following specific questions:

1) Why design a waste handling capacity of 500,000 cubic feet per year for a one-shift operation and 1,200,000 for a 3 shift operation (SAR Table 3.1-5) when plans are to ship less than 400,000 cubic feet per year?

2) Why is an operating life of 25 years assumed, when the 6.2 million cubic foot capacity would be filled in 16 or 17 years at the planned shipping rate?

3) Why are only $2 / 3$ of the retrievable wastes generated at DOE facilities between the present and 1.990 assumed to be shipped to WIPP? What plans are there to dispose of the other $1 / 3$ of the waste?

4) Why are the presently stored retrievable wastes at DOE facilities other than INEL not going to be shipped to WIPP? Where will these wastes be disposed?

5) Why does the transportation analysis assume that wastes will come only from INEL and RFP?

As presently defined the WIPP project would be unable to dispose of TRU wastes thit are presently stored at DOE facilities other than INEL, stored alter the year 2003, buried, and generated by decontamination and decommissioning activities. 
Since the above facts suggest that a larger repository is possible, the following questions should be answered:

1) What is the probability that this volume will be increased substantially? What might the maximum volume be?

2) What effect would an increased waste storage volume have on the environmental and radiological health aspects of waste transportation, facility operation, and a repository breach?

3) What procedural requirements under the NEPA process would be necessary before the radioactive waste storage capacity could be substantially increased? 
The Final EIS expanded the discussion of controls after decommissioning and this considerably strengthened the section and satisfactorily addressed some of our concerns. Our requests for more information on 1ong-term controls over shallow well drilling and resource extraction were not answered. Neither was a commitment made to our recommendation for long term monitoring.

We believe that drilling into the repository could occur from a variety of activities (e.g. for hydrocarbon recovery at greater depths, from exploration of the repository for possible recovery of gas or other minerals, and from potash extraction) and this may be the most likely way that a repository breach would occur. Furthermore, well drilling into the Rustler aquifer could also be a problem if breaching has previously occurred. The plans for written records, markers, and monuments are an important aspect of contro1 since they minimize the likelihood that drillers would have no knowledge of the repository. However, we are not fully convinced (page 15-46) that knowledge of a repository would be an adequate deterrent to man-made intrusion. Consequently, we believe there should be further evaluation of the need for positive control of drilling at the site.

An effective control period of up to 400 years (as suggested on page 15-46) might be optimum. The initial hazard from the estimated repository inventory is dominated by strontium-90 until about 300 years and thereafter decreases stowly because Plutonium-239 is dominant.

\section{HEALTH EFFECTS}

'lhe issues involving health effects appear to have been adequately addressed in the FELS. 


\author{
Radiological Health Review \\ of the Final Environmental Impact Statement (DOE/EIS-0026) \\ Waste Isolation Pilot Plant, U. S. Department of Energy
}

Supplementary Comments

to

Review of Dec. 8, 1980

\author{
Environmenta1 Evaluation Group \\ Environmental Improvement Division \\ Health and Environment Department \\ State of New Mexico
}

January 15,1981 
FEIS EXECUTTVF SIMMARY

The Executive Summary of the FEIS was checked for consistency with Volumes $I$ and $I I$ and for any misleading statements. The following items were noted.

$3-3 *$

The security and sabotage statement about experimental HLW fails to mention there will also be a similar number of shipments leaving the site at the end of the experiments.

$\underline{3-6}$

The one chance in 40,000 per year probability used here and in Chapter 6 gives a misleading impression of the expected rarity of a severe accident. The probability of this severe an accident occurring is actually about 1 in 140 per year. The 1 in 40,000 number comes from multiplying the 1 in 140 probability by probability factors for occurrence in: (1) an urban area $(0.3)$; (2) with restrictive meterology $(0.2)$; and (3) with proper wind direction (0.06) to obtain maximum population doses. The accidents occurring with probabilities between 1 and 140 and 1 in 40,000 per year would be expected to result in the release of radioactive material and some radiation dose to people.

$\underline{4-5}$ to $4-8$

The section on geology is brief, and does not include any reference to pressurized brine reservoirs or to the zone of anomalous reflection (mentioned on p. 7-29, Volume I).

$4-8$

We do not believe the statement on this page "It is believed that deep dissolution will not affect the site for the next million years (Anderson, 1978)" accurately portrays Dr. Anderson's concerns about deep dissolution at the WIPP site. A more thorough review of his 1978 paper (Reference 13), as well

* This nmerical designation refers to the page number in the FEIS. 
as his more recent publications, indicate his view that the site may be breached at the repository horizon before the overlying salt is removed by surface water and groundwater flow. Hence, estimates of site stability based upon the rate of movement of a surface dissolution front may not be pertinent.

$\underline{6-1}$

While the sanitary waste discharge is estimated as 25,000 gallons per day, the same volume used in the DEIS, page 8-33 of the FEIS uses 45,000 gallons per day. 


\section{CHAPTER 1}

$1-4 ; 6 . \quad$ Hydrology

The conclusion that there is no deep dissolution active within 10 miles of the site should not be made until the zone of anomalous reflection, near the odso of zone rT, has heen adequately explained.

1-5;4. Alternaive 2. The authorized WIPP facility.

The statement is made that "the SPDV program has been planned to confirm the greologic adequacy of the site and to verify the engineering properties of the salt at the depth of the WIPP repository." We agree that the SPDV program will provide valuable information as to the engineering properties of the salt at the repository horizon. However, our review of the availahle information on the SPDV does not indicate how the program will resolve all of the questions relative to the geologic adequacy. For example, the zones of anomalous reflection needs further investigation to clarify this phenomenon. These questions should be resolved, since these zones could be interpreted as potential artesian brine pockets or advanced stages of deep dissolution in proximity to the repository horizon.

\section{$1-7 ; 2$}

This paragraph fails to point out that the maximum occupational 50 year dose commitment calculated ( $p .9-108)$ was 130 rem to the bone. This is about 20 times the 50 ycar background dose.

\section{$1-8 ; 5$}

The statement is made that the characteristics of the Los Medanos site do not appear to conflict with the draft criteria of the National Waste 'Terminal. Storage. (NWTS) program for qualifying sites for the disposal of commercially generated high-level waste (Reference 14). As indicated in our comments on $\Lambda$ ppendix D, there are several questions raised concerning whether the site meets certain of the criteria. 
CHAPTER 2

\section{Roferences for Chapter 2 .}

Several reference citations in the text are not listed in the reference list for Chapter 2. For example, (iriswold 1977; Snow and Chang 1975; Jones, 1974a; Jones, 1974b, Jones et al, 1973; ORNL, 1972; and others. It appears that a1l references with a first letter beyond " $D$ " in the alphabet were omitted. This makes it difficult to evaluate the information and data cited in the Chapter.

\section{CHAPTER 4}

\section{$4-12 ; 2$}

This paragraph states that a solution mining release scenario was not considered conceivable in the bedded salt at WIPP, "because of the relationship of the repository to geologic features (i.e., the presence of numerous thin layers of relatively impermeable anhydrite and polyhalite in the Salado) lack of economic incentive as compared to other salt deposits, and lack of large quantities of water." The FEIS contains no data to support the contention that the thin layers of anhydrite would be totally impermeable during solution mining. There are presently economic incentives to mine potash in the area, and if at some future date, a source of water becomes available, solution mining would become more likely. 
CHAPTER 7

The ples contains additional information on site surface water and groundwater hydrology. This information included responses to specific comments by FFC (Reference 2) on surface water use and on site storm water runoff. The additions are very helpful. Nlso, the planned hydrologic studies (p. 7-96) will address two items mentioned in a later report of EEG (Reference 7) as needing additional information (recharge areas and hydrologic systems and transit times.)

We have two additional concerns that may not be addressed by currently planned studies and evaluations. One is the need to quantify as much as possible the uncertaintios that exist in such key parameters as $K_{d}$, hydraulic conductivity, and porosity. There may be enough data presently available to do this in approximate form. The uncertainty analysis would give a range of possille values that would be much more meaningful than the single numbers used in various scenarios involving radionuclide transport. 'lhe second concern is whether the effects of future climatic changes on the current hydrologic regimen may be significant. One aspect of clinate change could be a change in hydraulic head relationships in the various aquifers. Planned future studies may provide an answer for this part of the problem. The second aspect is the possible increase in fracture permeability that might occur from further dissolution within the Rustler aquifers. The statement was made at EEG's January 1980 Geotechnical Meeting that it ma be possible to estimate the rates that permeability wi11 increase (Reference 7, page 9).

Thr following specific questions and comments are offered:

$7-82$

Ihe description of Pecos River water use below Carlsbad and below Red Bluff rescrvoirs is helpful. However the use of water in Pecos County, Texas and Jownstram lacks detail. Also, it is stated that the water, with a dischargoweighted 'J'los exceeding $15,000 \mathrm{mg} / \mathrm{l}$ is used for irrigation and stock watering. Is this high Tl)S water used only after blending with better quality water? 
$7-83$.

If stormwater rumblf drains inte Nash Draw, might it also he a source of recharge to the pecos River as the potash-refinery effluents are said to be (page 7-93)? Consideration should be given to estimating the quantities of radionuclides that might he carried offsite by stormwater runoff. Also the possibility that the nuclides might be concentrated in sediment at some point offsite should be investigated.

$7-89$.

This statement (lines 5 and 6) "Groundwater movement in the Rustler near the site is westward toward Nash Draw and then southward toward the Pecos River." is inconsistent with the sentence on pages $7-87,88$ "..the average groundwater gradient of the Magenta Dolomite and the Rustler-Salado contact is to the soutliwest and that of the Culchra Dolomite is to the southeast and then to the southwest."

$7-89$.

Several questions arise from the description of the Santa Rosa Sandstone aquifer:

(1) Is groundwater flow to the south (first paragraph and conclusion 8 - on page 7-96) or "into the pecos River rather than to the south into Texas" (second paragraph)?

(2) Where is the recharge area for the portion of the Santa Rosa aquifer overlying the WTPP site? What is the possibility that a wet hydrologic cycle would incrase the silurated thickness of this formation? If this occurred it could place an aquifer with good quality water immediately over horizons containing wistes.

$7-96$

When might information concerning hydrologic studies 1 and 2 be available? 
$8-4 ;$ Section 8.1 .2

From Figures 9-1, and 9-2, one can calculate that a shift in the site of 0.5 miles to the southwest would still meet the one mile borehole criterion and would reduce the area of langbeinite mineralization inside of Zone IV by more thin one square mile while increasing the amount of lease grade sylvite inside of 7one IV by less than one quarter square miles. Also this would be moving away from the zone of anomalous reflection. What considerations are being given to shifting the location or underground orientation of the repository as more data become available? 
CHAPTER 9

\section{General. Comments}

If the dose rates and dose commitment detailed in the FEIS are reasonable estimates for the scenarios considered it appears that there are few radiological problems of concern. In a number of instances, however, we need more definitive information concerning the fact that the kinetics and parameters used in arriving at these dose estimates indeed reflect actual environmental conditions at the site.

The following examples illustrate the lack of supportive data needed to perform independent analyses to confirm dose calculations.

$9-105$

Following the narrative of accident $\mathrm{R} 15$, one obtains a release of $2 \times 10^{-3}$ curie. Is there an assumption omitted that $1 \%$ of the waste released is suspended in the air? A factor of $10^{-2}$ is not explained.

$9-107 \quad$ Tab 1e $9-52$

The source term in Table 9-50 and 9-51 of FEIS are considerably higher than those in Table 9-23 and 9-24 of the DEIS. The dose commitments in Table 9-52 of FETS are also substantially higher than those in table 9-25 of DEIS. However, for the $\mathrm{CH}$-area accidents, the ratios of the source terms (FEIS/DEIS). This is questionable since the quantity of activity has changed, not the isotope spectra. Also, the natural background dose in Table $9-52$ is a 50 year dose.

\section{$9-112 ; 1$}

The list line of the paragraph states that all the radioactivity is released instantaneously. Iible 9-55 1 ists a release rate in $\mathrm{pCi} / \mathrm{sec}$. We have not been able to arrive at the numerical values in Table 9-55 from the information provided. 
9-130 (flow rates through we1lbore)

It appears that the data in Figure $K-11$ applies to scenarios 1,2 , and 3 . Presumahly, the data was obtained with the SWIFT code although it appears to be a combination of Darcy's law and Poiseuille's formula. The flow numbers in the three scenarios in section 9.7.1.3 cannot be obtained from Figure K-1. Some further explanation might be helpful.

\section{Specific Comments}

$\underline{9-6}$

In designing the size of the diked area to contain fluid runoff was the interception of a geopressurized brine reservoir considered? What is the total. containment volume?

$9-100: 4$

The last line mentions a total release of $6.9 \times 10^{-8}$ curie for accident C 10. The correct number should be $2.2 \times 10^{-9}$ as given in Table 9-50.

$9-101 ; 2$

The paragraph mentions a total activity of 376 curies. Calculations suggest that the correct value should be 326 .

9-104; Tab1e 9-51

What is the numerical value of the air volume of the cask, transporter, and waste cage that is displaced from the pit?. This value is needed in verification of the $\mathrm{C}-13$ consequences.

$9-127$

The curies of U-235 in Table $9-59$ should be 0.36 rather than 36 . 


\section{9-137 Nuclide Transport.}

The FEIS states, "The highly sorbed plutonium nuclides do not contribute to the discharge even at 3 million years; these species are retained in the aquifer near the repository, while their much less sorbed uranium dauphters are transported at about one-tenth the aquifer flow speed." Ihis statoment does not reflect the uncertainty associated with the distribution coefficients for many of the radionuclides. A member of the EBC has recently evaluated the significance of certain Rustler aquifer parameters for predicting long-term radiation doses from WIPP (Reference 15). This report has considered the uncertainty associated with plutonium distribution coefficients $\left(K_{d}\right)$. If a portion of the plutonium moves with a lower $\mathrm{K}_{\mathrm{d}}$, the radiological consequences in all of the 1iquid breach scenarios may be significant. 
APPENDTX D

SELECTION CRTTERIA FOR THE WTPP STTE

\section{D-2;4.5 Lateral extent}

The discussion in the fFIS of this criterion implies that there are no questionable structures or dissolution features near the repository horizon. As indicated in previous comments, the areas about 1 to. 3 miles north and 1 mile southwest of ERDA-9 at the level of the Castile, and below, has yielded anomalnus soismic reflection data, and possible structural faults in tho Castile. This data rase questions about the integrity of the structure in these areas. The repository will extend almost to the northern boundary of zone IT which would be within $\frac{1}{2}$ mile of the northern zone of anomalous reflection. Therefore there is insufficient data at this time to be certain that this criterion is met.

\section{D-2; 10 structure.}

WIPP-12 is at the edge of a possible anticlinal structure in the Castile, and the hole is also located. at the southern edge of one of the zones of anomalous reflection discussed above. Seismic reflection data also suggest faults in the area north of Zone II and southwest and south of ERDA-9. The seismic dita has insufficient resolution to know if geologic faults extond into the Saladn. Until more information is available, one cannot romelude that the Whlp site meets the structure criterion.

\section{D-3; 5 Dissolution.}

We agree that the edre of regional dissolution in the basin is in the vicinity of Nash Draw, and therefore would not pose a problem for the proposed repository: However the seismic reflection data, as discussed in the preceding pararaphs ma be indicative of dissolution features in proximity to the repository horizons. 
D-5; 9 Fauting and Fracturing.

This paragraph states that there are no known faults in post Permian rocks at the site area. As discussed above, the seismic reflection data do indicate the possibilitu of faults in the Castile. Therefore, it is not yet possible to know whether this criterion is met.

D-6; Salt-Flow Anticline.

As discussed in the preceding paragraphs, there could be a major anticline in the Castile beginning at the northern edge of Zone. II and extending north. There is a definite steepening and the seismic data do not permit an adequate resolution of the extent of this steepening toward the north. such structure is indicative of possible effect on long-term safety of the repository.

D-8: 7 Natural Resources.

The statement is made that:"very little potash exists above the repository (Zone J.I) itself." This statement conflicts with the information in Figure 2.7-6 of the SAR (Reference 13) which states that the McNutt member at ERDA-9. "contains potassic rock rich in sylvite, langbeinite and other hydrous minera1s." Also Figure 9-1 would suggest that at least $1 / 3$ of Zone II contains lease grade sylvite.

D-9; 2 Man-made Penetrations.

As indicated in other EEG comments on the FEIS, the possibility of human intrusion is of considerable concern, and therefore additional information is necded as to how cont ro 1 will be maintained. 
APPENDIX E

DESCRTPTIONS OF WASTE TYPES

The activity curve for $\mathrm{U}-234$ and Ra-226 in Figure E-2 can only be explained if there is a substantial amount of $\mathrm{U}-238$ in the waste; this is not apparent in table $\mathrm{E}-3$. The total activity curve in the time interval between $10^{5}$ and $10^{6}$ years seems to include $T h-230$ and all the radioactive daughters of Ra-226 that are in secular equilibrium. Some clarification might help. 


\section{APPENDIX J}

EFFLUENT AND ENVIRONMENTAL MEASUREMENTS PROGRAMS

The FEIS did not acknowledge or respond to EEG's comments concerning radiation monitoring programs. We believe these comments are still applicable and need to be addressed. The more important ones are:

\section{Present Program}

(1) "Radon emissions from natural radioactivity in the repository have not been measured in soil, mined rock, and the proposed waste horizon. Radon should he measured to see if levels might be high enough to be a problem for underground workers and a source of radiation exposure to the public..." (page 53, Reference 2).

(2) "It will be necessary to obtain sufficient samples and analyses before operation to ensure that the variations in the background (naturally occurring and from weapons testing fallout) levels of actinides,.... and fission products are adequately known. These values are needed in order to be able to detect contamination from site operations." (page 60, Reference 2)

\section{Pre-Operational and Operational Programs}

(3) "It is noted that no air particulate station is planned for Hobbs. Since it is a major population center, with a calculated long-term $X / Q$ only $10 \%$ lower than at Eunice, this omission should be reconsidered. Also, the three days per week of sampling should be randomized in order to measure levels on work days, and nonwork days." (page 60, Reference 2).

(4) "Consideration should also be given to monitoring radioactivity in rainfal1 and runoff (when it occurs) at the site as well as surface water and biota in Nash Draw." (page 57, Reference 2)

(5) "In several cases...the types of analyses are not specific enough. Gross analysis is useful as a screening mechanism for detecting significant contamination. However, it usually will not detect trace migration of radionuclides. All media being sampled should have periodic 
analyses of the actinides... and long-lived fission products." (page 58. Reference 2)

Post-operational Program

(6) "The outline of a post-operational program...appears reasonable. However, the borehole radionuclide analyses should be for specific radionuclides rather than gross alpha and beta analyses for the reasons discussed above." (page 61, Reference 2)

Several changes have been made in Appendix $J$ between the Draft and FEIS. One of these is substantive. In the DEIS (page J-30 and Tables J-5, J-6) it is stated that "In general, state-of-the-art techniques and instruments will be used." In the FEIS (page J-32) it is stated "The equipment used for measurement during operation will meet or exceed the sensitivities required to detect radiation levols below the limits described in 10CFR 20, Appendix B." The IOCFR 20 criteria would permit minimum detection levels that are one to three orders of magnitude less sensitive than would occur from state-of-the-art techniques. We believe that use of the 10CFR 20 criteria is unacceptable for environmental samples since it could result in some trace radionuclide releases not being detected. This position is consistent with the Nuclear Regulatory Commission Regulatory Guide 4-1 which states "the detection sensitivity of environmental measurements should be the most sensitive that is practically achievable for measuring plant contributed radionuclides in the environment."

11. the TLDs stations are along a line going N-E from the center of the WTPP facility. Some data points near the James Ranch might be desirable since it is the reference location for accident analysis. 
Water guality

D. $8-33$

The estimated rate of sewage discharge is 45,000 gallons per day. This disagrees with the DEIS and the Executive Summary, both of which use $25,000 \mathrm{gpd}$. Which is correct? Also, the statement in the DEIS that all treated waste water would be used for landscape irrigation or evaporated has been deleted. Has there been a change in the earlier plan to evaporate a11 excess water?

p. $14-7$

The term Water Ouality Division used twice in section 14.2 .5 should be Water Pollution control Bureau. The Water Pollution Control Bureau notified DOE on October 7, 1980 that a ground water discharge plan was not needed for the SPDV program.

\section{Air Quality}

P. $14-8$

The appropriate New Mexico Air Quality Regulation for new sources is 702, not 100. A permit was granted by the New Mexico Air Quality Bureau of June 6,1980 for the SPDV phase of the WIPP project.

\section{Noise}

The Fets was largely unresponsive to ElG comments on noise aspects in the Dlis. Of the 5 items we pointed out as needing clarification only one was partially responded to. None were acknowledged. The 4 possible mitigation measures suggested were ignored. We still believe these mitigation measures have the potential for reducing noise exposure of workers and those living along right-of-way and should be considered. 
1) busing of workers to drastically reduce auto traffic;

2) muffling of construction equipment and use of low noise products where availahle;

3) a requirement that all tricks meet the Federal noise regulations required for inter-state commerce: and

4) bousing of various fixed noisy equipment and operations. 


\section{REFERENCES}

1. Environmental Evaluation Group. Review Comments on Geologica1 Characterization Report, Waste Isolation Pilot Plant (WIPP) Site, Southeastern Now Mexico. SAND 78-1596, Volumes I and II, December 1978 (EEG-2), August 1979 .

2. Neil1, Robert II., et al. Radiological Health Review of the Draft Environmental Impact Statement (DoE/EIS-0026-D) Waste Isolation Pilot Plant, U.S. Department of Energy (EEG-3), August 1979.

3. Sandia National Laboratories. Summary of Research and Development Activities in Support of Waste Acceptance Criteria for WIPP, (SAND 79-1305), November 1979.

4. Little, Marsha11 S. Review Comments on the Report of the Steering Committee on Waste Acceptance Criteria for the Waste Isolation Pilot Plant (EEC:4), Fobruary 1980 .

5. Irby, II.H., ed. Report of the Steering Committee on TRU Waste Acceptance Criteria for the Waste Isolation Pilot Plant (WIPP-DoE-069), May 1980.

6. Channe1.1, James K. Calculated Radiation Doses From Deposition of Material Released in Hypothetical Transportation Accidents Involving WIPP-Related Radioactive Wastes (EEG-5), October 1980 .

7. Environmental Evaluation Group: "Geotechnical Considerations for Radiological. Hazard Assessment of WIPP: A Report of a Meeting HeId on January $17-18,1980(E E G-6)$, Apri1 1980.

8. U. S. Department of linergy. Waste Isolation Pilot Plant, Safety Analysis Report, 5 vols., loso 
9. Chaturvedi, Lokesh. WIPP Site and Vicinity Geological Field Trip: A Report of a Field Trip to the Proposed Waste Isolation Pilot Plant Project in Southeastern New Mexico, June 16 to 18, 1980 (EEG-7', october 1980 .

10. Coal, bonna. A Compilation of Site Selection Criteria, Considerations and Concerns Appearing in the Literature on the Deep Disposal of Radioactive Wastes (EEG-1), June 1979 .

11. U.S. Department of Energy. Draft Environmental Impact Statement, Waste Isolation Pilot Plant (DOE/EIS 0026-D), 2 vols., April 1979.

12. Sandia National Laboratories. Geological Characterization Report, Waste Isolation Pilot Plant (WIPP) Site Southeastern New Mexico (SAND 78-1596), 2 vols. December 1978.

13. Anderson, Roger $Y$. Deep Dissolution of Salt, Northern Delaware Basin, New Mexico (prepared for Sandia Laboratories), revised April 1978.

14. Oftice of Nuclear Waste Isolation. NWTS Criteria for the Geologic Disposal of Nuclear Wastes: Site Qualification Criteria (ONWI-33 (2)), January 1980 .

15. Wofsy, Carla. The Significance of Certain Rustler Aquifer Parameters for Predicting Long-Term Radiation Doses from WIPP (EEG-8), September 1980. 